\title{
Health Self-Awareness in Senior Citizens: Focus on Physical, Emotional and Cognitive Health
}

\author{
Eliane Ferreira Carvalho Banhato ${ }^{1}$, Pricila Cristina Correa Ribeiro², \\ Danielle Viveiros Guedes ${ }^{3}$, Cláudia Helena Cerqueira Mármora ${ }^{4}$, Roberto Alves Lourenço ${ }^{5}$ \\ ${ }^{1}$ Faculty of Psychology, Centro de Ensino Superior de Juiz de Fora-CESJF, Juiz de Fora, Brazil \\ ${ }^{2}$ Department of Psychology, Faculty of Philosophy and Humanities, Federal University of Minas Gerais, Belo \\ Horizonte, Brazil \\ ${ }^{3}$ Empresa Brasileira de Pesquisa Agropecuária, Sinop, Brazil \\ ${ }^{4}$ Department of Psysiotherapy Elderly, Adult and Mother and Infant, Faculty of Psysiotherapy, Federal \\ University of Juiz de Fora, Juiz de Fora, Brazil \\ ${ }^{5}$ Department of Internal Medicine, Faculty of Medical Sciences, State University of Rio de Janeiro, Rio de \\ Janeiro, Brazil \\ Email: ebanhato@gmail.com
}

Received 7 April 2015; accepted 9 June 2015; published 12 June 2015

Copyright (C) 2015 by authors and Scientific Research Publishing Inc.

This work is licensed under the Creative Commons Attribution International License (CC BY).

http://creativecommons.org/licenses/by/4.0/

(c) (i) Open Access

\section{Abstract}

Senior people usually express high levels of satisfaction and quality of life, even though they may be facing comorbidities and disabilities. This is an evidence of how unreliable quantitative measures, taken alone, can be when trying to understand the health levels of this population. Health self-awareness has been widely used in order to assess the health of old people. The present study describes how a sample of Brazilian senior citizens assesses their general health and verifies the relationship between negative health self-awareness and social-demographic factors as well as physical, emotional and cognitive impairment in this population. There were 427 senior subjects in the sample aged 65 or more from both genders. The primary outcome was assessed by the question: "on the whole, how do you assess your health?". This variable was divided into 2 groups: positive perception (options very good and good) and negative perceptions (options fair, bad and very bad). The independent variables were: social demographic; physical aspects of health; emotional and humour aspects; and cognitive aspects. In our studies, $42.4 \%$ of seniors had negative health self-awareness. The logistic regression analyses showed that the social demographic factor could explain negative health self-awareness in $62.4 \%$ of the subjects. However, only the association with education was statistically significant $(p<0.001)$. Diabetes, self-referred depression and instrumental activities were statistically related to the worse health self-awareness $(p=0.01 ; 0.05$; 0.02 and 0.05 , respectively). The emotional aspect was responsible for $64.9 \%$ of the negative 
health self-awareness $(p<0.001)$, while the cognitive aspect $(p=0.052)$ had a predictive value of $57.6 \%$. From the findings in the present study, it is possible to conclude functional loss and the presence of chronic diseases is not enough to explain negative health self-awareness in old people. It is important to take into account education and the presence of depressive symptoms.

\section{Keywords}

\section{Health Self-Awareness, Aging, Senior People, Self-Rated Health, Elderly}

\section{Introduction}

Aging is both complex and heterogeneous process due to several physical, emotional and social factors. Therefore, it is difficult to objectively evaluate the health of senior people. As a consequence, it is hard to predict and control negative outcomes in old patients. Senior people usually express high levels of satisfaction and quality of life, even though they may be facing comorbidities and disabilities (Lima, Silva, \& Galhardoni, 2008). This is an evidence of how unreliable quantitative measures, taken alone, can be when trying to understand the health levels of this population.

Health self-awareness, i.e. a self evaluation of someone's functional state, has been widely used in order to assess the health of old people. According to Freitas et al. (2006), self-awareness is the result of physical and mental impairments related to aging and it is associated with environmental factors, making it a more reliable measure.

The advantage of using health self-awareness lies on its simplicity and on its ability to capture people's perceptions so that relevant data can be obtained. These data can be used to predict mortality risk, morbidity, functional limitations and the use of health services (Pagotto, Bachion, \& Silveira, 2013; Singh-Manoux et al., 2007; Lebrão \& Laurenti, 2005; Alves \& Rodrigues, 2005; Barros, 2005; Marcellini et al., 2002). Therefore, although health self-awareness measures can be subjective, its importance has been increasing in the last decades, particularly in epidemiological research, because of its closeness to the real state of health of the patient (Alves \& Rodrigues, 2005).

Pagotto, Bachion e Silveira (2013), in a recent systematic review, pointed out that in population surveys with old people, health evaluation had been done not only with objective test, such as laboratory exams and functional scores and expert observation, but also with the measurement of the old patient's perception about his/her health. The result is an evaluation based on personal beliefs.

The main factors associated with health self-awareness are: demographic (age, gender, marital status, family arrangement), social and economical (education and income), number of chronic diseases (hypertension, arthritis and rheumatism, cardiovascular disease, diabetes, stroke and cancer) and functional capability (Mendes da Costa, 2013). It is yet unclear the reasons for this association. In an attempt to explain it, several hypotheses have been raised. For instance, one hypothesis states that a bad or very bad self-awareness can be due to lack of preventive practices in health or compliance to medical treatment (Södergren et al., 2012). Another hypothesis deals with the fact that bad self-awareness can be associated with a negative impact from the nervous system into the immunological system, making the person more likely to develop diseases (Silva \& Menezes, 2007).

According to Pagotto et al. (2011), social demographic variables (sex, age, education, family arrangement) interfere in self-awareness because they reflect a scenario of inequalities in Brazil, with a direct impact on health. Nunes et al. (2012) in a study with a considerable sample of senior people from a town near Belo Horizonte/MG showed that a bad health evaluation was associated with a negative perception of personal relationships and the feeling of carelessness in case of bed rest. These authors did not find variation in the health self-awareness between genders and age groups. The latter demographic variables are less relevant to health self-awareness (Paskulin \& Vianna, 2007; Lima-Costa, Firmo, \& Uchoa, 2004). Among the social demographic aspects, income seems to influence negative self-awareness the most (Yao, 2008; Singh-Manoux et al., 2007; Alves \& Rodrigues, 2005; Silva \& Menezes, 2007).

It is thought that the presence of chronic diseases can influence the health self-awareness (Christian et al., 2011). The boletim PAD-MG (Minas Gerais, 2004) identified that most chronic disease free people had a posi- 
tive assessment of their own health (good or very good) (84.1\%), whereas among those who had at least one chronic disease only $39.5 \%$ mentioned that their health was good or very good.

In 2008, Theme-Filha et al. showed that the worst health self-assessment came from people who had diabetes, angina and arthritis. Likewise, Hartmann (2008) conducted a study with senior citizens from Porto Alegre and identified a relationship between physical impairment or depressive signs and mainly regular health self-awareness.

Functional capacity is another aspect that has proved to be one of the main determinants of perception for old people about their own physical condition. It has been considered a new health paradigm (Alves \& Rodrigues, 2005). Assessing functional capacity, in this way, is important in order to choose the best kind of intervention and monitoring the health of old people. Maia et al. (2006) showed that senior people with a bad self-awareness had a risk factor 2.69 times higher for mortality than those who thought of their health as excellent.

Consequently, it is possible to raise the hypothesis that on the one hand positive health self-awareness relates directly with the subjective experience of well-being and to good quality of life at old-age. On the other hand, negative health self-awareness results from physical, cognitive and emotional impairment and interferes in the search of medical assistance as a whole. Therefore, knowing the role that different variables may play in the way that individuals are aware of their own health may help in the introduction of more efficient clinical interventions once self-awareness is related to the pursuing of early diagnosis, treatment adherence and disease prevention. Thus, it is important to investigate not only physical factors but also demographic, social and psychological aspects that may be related to health self-awareness of old people. The present study describes how a sample of Brazilian senior citizens assesses their general health and verifies the relationship between negative health selfawareness and social-demographic factors as well as physical, emotional and cognitive impairment in this population.

\section{Methods}

This is a cross-sectional cohort study in the urban area of the city of Juiz de Fora, in Minas Gerais state. There are $14 \%$ of old people in this population (IBGE, 2010). A representative sample of senior people was used to form the database of a multicentric project called Fragilidadeemidososbrasileiros (Rede Fibra). Out of 16 territorial units, 5 were randomly selected. Each neighbourhood in the selected territorial unit should have had $10 \%$ of its old citizens interviewed. Eligible participants received individual explanation of study purpose, objectives and procedures. Upon agreeing to participate, participants signed informed consent.

There were 427 senior subjects in the sample aged 65 or more from both genders. The primary outcome was assessed by the question: "on the whole, how do you assess your health?”. Answers were gathered in a Likertlike scale with 5 options (very good, good, fair, bad, very bad). Later, this variable was divided into 2 groups: positive perception (options fair, very good and good) and negative perceptions (options average, bad and very bad).

The independent variables were put together in 4 domains: i) social demographic (age, gender, marital status, income, family arrangement and education); ii) physical aspects of health (self-related diagnosis of chronicle diseases, such as arthritis, rheumatism, cancer, diabetes mellitus, systemic arterial hypertension, heart diseases, chronic kidney failure, lung diseases, depression and osteoporosis); basic and instrumental activities of daily living; current smoking and any alcohol intake in the last 30 days; iii) emotional and humour aspects; iv) cognitive aspects.

In the social demographic domain, age variable was divided into 3 categories: 65 - 74; 75 - 84 and 85 or older. Marital status was categorized into 4 groups: married or living with a partner, single, divorced or widower. Family arrangement was divided into 2 categories: living alone, or at least one other person. As for education, 3 groups were created: low (0 to 3 years), intermediate (4 to 7 years) and high (8 years or more). In order to adjust the multiple logistic regression models a continuous variable was used related to total years of education. As for the income, there were three categories: up to 1 minimum wage, 1 to 3 minimum wages and 3 or more minimum wages.

The instrumental activities were assessed through the Lawton Scale (Lawton \& Brody, 1969). In this scale, which was adapted to the Brazilian context (Santos \& Virtuoso Júnior, 2008), the elderly person has the following levels of performance: without assistance (3 points); partial assistance (2 points) and unable to perform (1 point). The maximum score is 21 points, which means independence. Scores between 5 and 20 represent partial dependence and a score lower than 5 means total dependence. The performance of daily basic activities was assessed according to the Katz index (Katz, 1963). The total score in this scale is 6 points, which means inde- 
pendence. 4 points means partial dependence and 2 points means significant dependence. Both emotional and humour aspects were assessed through the Geriatrics Depression Scale (GDS) (Yesavage et al., 1983), screening instrument which investigates 15 items. The score can vary from 0 to 15 . A score greater than five indicates possible depression (Almeida \& Almeida, 1999).

The cognitive aspects were investigated through the Mini Mental State Examination (MEEM) (Folstein et al., 1975). There are 30 items in this exam. They are used to evaluate space and time orientation, immediate memory, evocation memory, procedure memory and language. The score varies from 0 to 30 points. In order to qualify for this study a minimum score of 13 was required. The cut off point was used according to Almeida (1998): 19/20 for educated subjects, and 23/24 for those with some degree of education. The subjects were hence divided into 2 groups: without a disorder and with a disorder. The statistical analyses were carried out through the 15 Statistical Package for the Social Sciences for Windows (SPSS) programme. To create absolute and relative frequency tables, the mean and the standard deviation. The association between the independent variables and the health self-awareness was conducted through qui-square test. All the variables with statistical significance ( $p$ $<0.05$ ) were included in the binary logistic regression model.

\section{Results}

From the 427 senior citizens in the study, 42.4\% (181) assessed their own health as negative (average bad or very bad). The subjects were aged between 65 and 97 years old with a mean of $74.44(S D=6.87$ ) years. The majority (55\%) were aged 65 to 74 years old. Table 1 describes health self-awareness (negative or positive) according to social demographic, physical, cognitive and emotional features.

In the univariate analyses, social demographic domain, income and education level were negatively associated with health self-awareness in the univariate analyses. In the group with positive health self-awareness the mean income was $\mathrm{R} \$ 1,372.16$ ( $\mathrm{SD}=1,543.20$ ) and $5.7 \%$ were illiterate. In the group with negative health self-awareness, the mean income was $\mathrm{R} \$ 981.76(\mathrm{SD}=\mathrm{R} \$ 1,067.29)$ and $12.7 \%$ were illiterate. Sex, age, marital status and family arrangements were not associated with health self-awareness. The increase in the number of diseases was associated with the worst health self-awareness $(p=0.025)$. To the subjects who self assessed health as positive, the average number of pathologies was $1.08(\mathrm{SD}=0.99)$ and to the group who assessed their health as negative, the average was $1.39(\mathrm{SD}=1.13)$. The morbidities which were significantly associated with negative health self-awareness were stroke $(p=0.005)$; diabetes $(p=0.002)$, depression $(p=0.003)$ and urinary incontinence $(p=0.002)$. Arterial hypertension, cancer, arthritis, chronic obstructive pulmonary disease and osteoporosis were not associated with health self-awareness.

Regarding functional capacity, the independence on basic activities of daily living was found in $97.2 \%$ of the subjects. The independence on instrumental activities was found in 60.2\% (257) and partial dependence in 107 subjects (39.8\%). Among those with positive health self-awareness, 67.7\% (164) were totally independent, whereas $33.3 \%$ 82) were partially dependent. Among those with negative self-awareness, $51.4 \%$ (93) were independent and $48.6 \%$ (88) were partially dependent for instrumental activities. 8.2\% (35) were smokers and 8.9\% (38) drank 2 or more alcoholic shots a day. These variables were not associated with health self-awareness.

In the emotional aspect, $23.9 \%$ (102) of the subjects were found to have depressive symptoms. In the positive health self-awareness group, 15\% (37) had depressive symptoms and in the negative health self-awareness, 35.9\% (65) had these symptoms.

Regarding cognitive aspects, 33.5\% (143) had some disorder. In the positive health self-awareness group 29.7\% (73) had cognitive disorders. In the negative health self-awareness group, 38.7\% (70) had these disorders.

The logistic regression analyses showed that the social demographic factor could explain negative health selfawareness in $62.4 \%$ of the subjects. However, only the association with education was statistically significant ( $p$ $<0.001)$. Diabetes, self-referred depression and instrumental activities were statistically related to the worse health self-awareness ( $p=0.01 ; 0.05 ; 0.02$ and 0.05 , respectively). The emotional aspect was responsible for $64.9 \%$ of the negative health self-awareness $(p<0.001)$, while the cognitive aspect $(p=0.052)$ had a predictive value of $57.6 \%$.

The logistic model with all the significant variables had an explanatory power of $68.7 \%$. However, only education, diabetes and depressive symptoms were significant (Table 2). Finally, the adjusted model with only those variables had an explanatory power of $65.4 \%$, which means that these are the best factors to explain health self-awareness in this population. Education had a negative association in the model, which means that this 
Table 1. Health self-awareness according to social demographic, physical, emotional and cognitive features-FIBRA/JF, de Fora, MG, Brazil, 2009 ( $\mathrm{N}$ = 426).

\begin{tabular}{|c|c|c|c|c|c|}
\hline & & \multicolumn{3}{|c|}{ Health self-awareness } & \multirow[t]{3}{*}{$\chi^{2}(p$-value $)$} \\
\hline \multirow{2}{*}{ Variables } & & Total & Positive & Negative & \\
\hline & & N (\%) & N (\%) & N (\%) & \\
\hline \multicolumn{6}{|l|}{ Domain I } \\
\hline & Gender & & & & $\begin{array}{c}\chi^{2}=0.437 \\
p=0.509\end{array}$ \\
\hline & Men & $130(30.4)$ & $78(31.7)$ & $52(28.7)$ & \\
\hline & Women & 297 (69.6) & 1168 (68.3) & 1129 (71.3) & \\
\hline & Age & & & & $\begin{array}{c}\chi^{2}=0.096 \\
p=0.953\end{array}$ \\
\hline & $60-74$ & $235(55.0)$ & $138(56.1)$ & 97 (53.6) & \\
\hline & $75-84$ & $153(35.8)$ & $84(34.1)$ & 69 (38.1) & \\
\hline & $\geq 85$ & $39(9.1)$ & $24(9.8)$ & $15(8.3)$ & \\
\hline & Marital status & & & & $\begin{array}{c}\chi^{2}=2.589 \\
p=0.459\end{array}$ \\
\hline & Married & 205 (48) & $120(48.8)$ & $85(47.0)$ & \\
\hline & Widower & 153 (35.8) & $21(8.5)$ & $20(11.0)$ & \\
\hline & Single & $41(9.6)$ & $13(5.3)$ & 15 (8.30) & \\
\hline & Divorced & $28(6.6)$ & $92(37.4)$ & 61 (33.7) & \\
\hline & Family arrangement & & & & $\begin{array}{c}\chi^{2}=0.344 \\
p=0.557\end{array}$ \\
\hline & Alone & 59 (13.8) & $36(14.6)$ & $23(12.7)$ & \\
\hline & More than 1 & 367 (85.9) & $209(85.0)$ & 1158 (87.3) & \\
\hline & Income $^{*}$ & & & & $\begin{aligned} \chi^{2} & =12.536 \\
\boldsymbol{p} & =\mathbf{0 . 0 0 2}\end{aligned}$ \\
\hline & 0 to 1 sal. & $172(40.3)$ & $84(34.1)$ & $88(48.6)$ & \\
\hline & 2 to 3 sal. & 139 (32.6) & 81 (32.9) & $58(32.0)$ & \\
\hline & More than 3 & $116(27.2)$ & 81 (32.9) & 35 (19.3) & \\
\hline & Education & & & & $\begin{array}{c}\chi^{2}=28.330 \\
\boldsymbol{p}<\mathbf{0 . 0 0 1}\end{array}$ \\
\hline & Low & 139 (32.6) & $61(24.8)$ & 78 (43.1) & \\
\hline & Medium & 169 (39.6) & $94(38.2)$ & 75 (41.4) & \\
\hline & High & 119 (27.9) & $91(37.0)$ & 28 (15.5) & \\
\hline \multicolumn{6}{|l|}{ Domain II } \\
\hline & Number of Diseases & & & & $\begin{aligned} \chi^{2} & =12.239 \\
\boldsymbol{p} & =\mathbf{0 . 0 0 7}\end{aligned}$ \\
\hline & None & $138(32.3)$ & $86(35.0)$ & $52(28.7)$ & \\
\hline & One & $131(30.7)$ & $82(33.3)$ & $49(27.1)$ & \\
\hline & Two & 89 (20.8) & $51(20.7)$ & $38(21.0)$ & \\
\hline & Three or more & $69(16.2)$ & $27(11.0)$ & $42(23.2)$ & \\
\hline & Diabetes & & & & $\begin{aligned} \chi^{2} & =10.020 \\
\boldsymbol{p} & =\mathbf{0 . 0 0 2}\end{aligned}$ \\
\hline & Yes & 45 (10.5) & $16(6.5)$ & $29(16.0)$ & \\
\hline & No & 382 (89.5) & 230 (93.5) & $152(84.0)$ & \\
\hline
\end{tabular}




\section{Continued}

Depression

Yes

No

Urinary incontinence

Yes

No

Functional capacity

AIVDs

Independent
Parcial dependence

Total dependence

ABVDs

More functional

Intermediate func.

Total dep.

Smoking

Alcohol intake

Domain III

GDS

With symptoms

Without symptoms

143 (33.5)

284 (66.5)

37 (15)

2207 (84.1)

242 (98.4)

4 (1.60)

$23(9.3)$

27 (10.9)

38 (10.5)

Domain IV

MEEM

With impairment

143 (33.5)

73 (29.7)

284 (66.5)

Without impairment

1173 (70.3) $\begin{aligned} \chi^{2} & =8.878 \\ p & =0.003\end{aligned}$

$p=0.003$

37 (20.4)

144 (79.6)

$$
\chi^{2}=9.507
$$$$
\boldsymbol{p}=\mathbf{0 . 0 0 2}
$$

59 (32.6)

$122(67.4)$

70 (38.7)

$\chi^{2}=2.980$

$p=0.084$

174 (96.1)

7 (3.90)

$12(6.6)$

$\chi^{2}=1.788$

$p=0.409$

$\chi^{2}=1.007$

18 (10.1) $\quad \begin{aligned} & \chi \\ & p=0.800\end{aligned}$

$p<0.001$

665 (35.9)

1116 (64.1)

$\chi^{2}=3.791$

$p=0.052$

*Minimum salary in 2009 was R\$465.00.

variable is a protective factor for negative health self-awareness.

Those subjects who had diabetes had 2.5 times higher a chance of a negative health self-awareness compared to diabetes free individuals. The presence of depressive symptoms increased by 3 the chance of negative health self-awareness.

\section{Discussion}

This study showed that the majority of senior citizens had a positive health self-awareness (57.6\%). The results could be due to the healthy profile of the suited population, in which $32.3 \%$ reported no chronic disease and $60.2 \%$ claimed to be independent for instrumental activities.

There are few studies about health perception of old people. The results found in the literature show a great variability in the outcome of health perception as bad/very bad. In the PNAD study (Lima-Costa et al., 2007), for instance, the data showed that $12.6 \%$ of old people assessed their health as bad, whereas in our study it was 4.4\% $(\mathrm{n}=181)$. The same result was seen in Hartmann (2008) with old people in Porto Alegre. However, 
Table 2. Estimated parameters and odds ratio of logistic models for negative health self-awareness in old people FIBRA/JF, Juiz de Fora MG, Brasil 2009.

\begin{tabular}{|c|c|c|c|c|c|}
\hline & \multirow[t]{2}{*}{ Predictors } & \multicolumn{2}{|c|}{ MODEL I } & \multicolumn{2}{|c|}{ MODEL II } \\
\hline & & B & OR (95\%CI) & B & OR (95\%CI) \\
\hline \multicolumn{6}{|l|}{ Domain I } \\
\hline \multicolumn{6}{|c|}{ Income } \\
\hline & $<1$ salary & 0.000 & 1.00 & & \\
\hline & 1 to 3 salaries & 0.358 & $1.43(0.80-2.57)$ & & \\
\hline & 3 or more & 0.199 & $1.22(0.69-2.17)$ & & \\
\hline & Education & $-0.099^{\mathrm{a}}$ & $0.91(0.85-0.97)$ & $-0.121^{\mathrm{a}}$ & $0.89(0.84-0.94)$ \\
\hline
\end{tabular}

Domain II

$\begin{array}{ccc}\text { Number of diseases } & & \\ \text { None } & 0.000 & 1.00 \\ \text { One } & -0.002 & 0.10(0.46-2.16) \\ \text { Two } & -0.293 & 0.75(0.37-1.52) \\ \text { Three or more } & -0.376 & 0.69(0.34-1.40)\end{array}$

Diabetes

$\begin{array}{ccccc}\text { No } & 0.000 & 1.00 & 0.000 & 1.00 \\ \text { Yes } & 0.880^{\mathrm{b}} & 2.41(1.10-5.26) & 0.876^{\mathrm{b}} & 2.40(1.21-4.76)\end{array}$

Incontinence

$\begin{array}{ccc}\text { No } & 0.000 & 1.00 \\ \text { Yes } & -0.400 & 0.67(0.38-1.17)\end{array}$

Functional capacity

for AIVD

Independent

0.000

1.00

Partial dep.

$-0.294$

$0.75(0.48-1.17)$

Domain III

\section{GDS}

$\begin{array}{ccccc}\text { Without symptoms } & 0.000 & 1.00 & 0.000 & \\ \text { With symptoms } & 0.962^{\mathrm{a}} & 2.62(1.59-4.32) & 1.094^{\mathrm{a}} & 2.98(1.85-4.83)\end{array}$

Domínio IV

\section{MEEM}

Without impairment

0.000

1.00

With impairment

$-0.028$

0.97 (0.61 - 1.56)

${ }^{\mathrm{a}} p<0.001 ;{ }^{\mathrm{b}} p<0.05$.

Pagotto, Bachion e Silveira (2013) showed very different results. According to them more than $25 \%$ of the old people thought their health was bad.

Regarding the physical factors associated with health self-awareness, the results of the present study showed 
that diabetes was associated with negative health self-awareness. These results are according to the literature (Theme-Filha et al., 2008; Hartmann, 2008). Possible explanations for this outcome include: the necessity of a change in the lifestyle, the presence of morbidities, depressive symptoms commonly found in diabetic patients (Badawi, et al., 2012). On the other hand, our results differ when it comes to other pathologies and the loss of functional capacity, frequently found associated to worse health self-awareness in senior people (Lima-Costa, Firmo, \& Uchoa, 2004; Alves \& Rodrigues, 2005; Wang et al., 2006; Sun et al., 2007). The lack of association of comorbidities to health self-awareness could be explained by the low prevalence of chronic pathologies in the subjects of this study. Regarding the social demographic factors related to health self-awareness, the association between lower income and bad health self-awareness lost its significance when compared to other demographic, physical, emotional and cognitive variables. This could be explained by the fact that a comfortable financial situation to buy medication, food and clothes may be associated with health awareness. On the other hand, low education was associated with negative health self-awareness, regardless of the other variables, which is in accordance with the literature (Alves \& Rodrigues, 2005; Carvalho et al., 2012; Hartmann, 2008). It is worth to point out that low education could be associated with a bias to answer the questions due to possible difficulties in the understanding of the questions. However, low education is a factor highly associated with adverse outcomes in the literature, such as chronic pathologies, functional loss, cognitive impairments, in addition to less access to health care services (Parahyba, Veras, \& Melzer, 2005; Rosa et al., 2003; Diniz, Volpe, \& Tavares, 2007).

There is no agreement in the sex variable in the literature. Some studies did not find differences between the sexes for health self-awareness (Paskulin \& Vianna, 2007; Nunes, 2012; Borim et al., 2014), whereas others identified women as having the more negative health self-awareness (Alves \& Rodrigues, 2005; Lima-Costa, Firmo, \& Uchoa, 2004; Oliveira, Neri, \& D'elboux, 2013). There was even another study that found that men had a more negative health self-awareness when there was no pathologies or in the presence of up to two morbidities (Alves \& Rodrigues, 2005; Sun et al., 2007). In the present study, there was no difference between the sexes, nor among different ages. Other studies showed that age was not associated with health self-awareness in old people (Lima-Costa, Firmo, \& Uchoa, 2004; Hartmann, 2008; Oliveira, Neri, \& D’elboux, 2013).

The present study did not find a significant association between cognitive impairment and health self-awareness. This could be explained by the fact that our sample contained old people without severe functional or cognitive impairment. However, the use of health self-awareness measurement may not be suitable in samples with cognitive impairment. Although some studies use the perception from the caregiver, it is important to take into account possible differences between the perception from the old person and a caregiver. Alves and Rodrigues (2005), for instance, showed that the chance to self-evaluate the health as bad was $47 \%$ lower among the old people who answered the questions for themselves compared to those answered by the caregiver.

According to the literature, the old people with depressive symptoms had 3 times more chance of negative health self-awareness. In Spain, a study carried out with 417 old citizens identified a chance of 2.38 times for bad health self-awareness (Torija et al., 2007). Likewise, Alvarenga et al. (2010) found 2.65 times more chance of depressed people to have average health self-awareness and a chance of 12.38 times to consider their health bad or very bad. These findings are important to lead discussions about depressive symptoms in old people.

A limitation on the present study refers to the epidemiological cohort study design, which limits the assessment of causal relation among variables. Future longitudinal research should be implemented to assess the causal relationship between multiple variables impacting aging. Furthermore, future studies should compare the self-perceived health among older adults in different residential contest (e.g. nursing home, jails, religious institutions). Understanding the role of self-perceived health among different subgroups will likely have an impact on the development of interventions and programs designed to foster successful aging.

\section{Conclusion}

From the findings in the present study, it is possible to conclude that aging, functional loss and the presence of chronic diseases are not enough to explain negative health self-awareness in old people. It is important to take into account education and the presence of depressive symptoms. Therefore, the identification of health determiners in old people should take into consideration factors in addition to the physical dimension, mainly when dealing with old people without functional impairment. 


\section{References}

Almeida, O. P. (1998). Mini Exame do Estado Mental e o diagnóstico de demência no Brasil. Arquivos de Neuro-Psiquiatria, 56, 605-612. http://dx.doi.org/10.1590/S0004-282X1998000400014

Almeida, O. P., \& Almeida, S. A. (1999). Confiabilidade da versão brasileira da Escala de Depressão em Geriatria (GDS) versão reduzida. Arquivos de Neuro-Psiquiatria, 57, 421-426. http://dx.doi.org/10.1590/S0004-282X1999000300013

Alvarenga, M. R. M., Oliveira, M. A. C., Faccenda, O., Cerchiari, E. A. N., \& Amendola, F. (2010). Sintomas depressivos em idosos assistidos pela estratégia saúde da família. Cogitare Enfermagem, 15, 217-224. http://dx.doi.org/10.5380/ce.v15i2.17850

Alves, L. C., \& Rodrigues, R. N. (2005). Determinantes da autopercepção de saúde entre idosos do Município de São Paulo, Brasil. Revista Panamericana de Salud Pública, 17, 333-341. http://dx.doi.org/10.1590/s1020-49892005000500005

Badawi, G., Gariépy, G., Pagé, V., \& Schmitz, N. (2012). Indicators of self-rated health in the Canadian population with diabetes. Diabetic Medicine, 29, 1021-1028. http://dx.doi.org/10.1111/j.1464-5491.2012.03571.X

Barros, M. B. A. (2005). Auto-avaliação de Saúde. In C. L. G. Cesar, L. Carandina, M. C. G. P. Alves, M. B. A. Barros, \& M. Goldbaum, Saúde e condição de vida em São Paulo-Inquérito multicêntrico de saúde no Estado de São Paulo-ISA/SP (pp. 173-182). São Paulo, SP: USP/FSP.

Borim, F. S. A., Neri, A. L., Francisco, P. M. S. B., \& Barros, M. B. A. (2014). Dimensions of Self-Rated Health in Older Adults. Revista de Saúde Pública, 48, 714-722. http://dx.doi.org/10.1590/S0034-8910.2014048005243

Carvalho, F. F., Santos, J. N., Souza, L. M., \& Souza, N. R. M. (2012). Análise da percepção do estado de saúde dos idosos da região metropolitana de Belo Horizonte. Revista Brasileira de Geriatria e Gerontologia, 15, 285-294.

http://dx.doi.org/10.1590/S1809-98232012000200011

Christian, L. M., Glaser, R., Porter, K., Malarkey, W. B., Beversdorf, D., \& Kiecolt-Glas, J. K. (2011). Poorer Self-Rated Health Is Associated with Elevated Inflammatory Markers among Older Adults. Psychoneuroendocrinology, 36, 14951504. http://dx.doi.org/10.1016/j.psyneuen.2011.04.003

Diniz, B. S. O., Volpe, F. M., \& Tavares, A. R. (2007). Nível educacional e idade no desempenho no Miniexame do Estado Mental em idosos residentes na comunidade. Revista de Psiquiatria Clínica, 34, 13-17. http://dx.doi.org/10.1590/S0101-60832007000100002

Folstein, M. F., Folstein, S. E., \& McHugh, P. R. (1975). Mini-Mental State: A Practical Method for Grading the Cognitive State of Patients for the Clinicians. Journal of Psychiatric Research, 12, 189-198. http://dx.doi.org/10.1016/0022-3956(75)90026-6

Freitas, E. V., Py, L., Cançado, F. A. X., Doll, J., \& Gorzoni, M. L. (2006). Tratado de Geriatria e Gerontologia (2nd ed.). Rio de Janeiro: Guanabara Koogan.

Hartmann, A. C. V. C. (2008). Fatores associados a autopercepção de saúde em idosos de Porto Alegre. Thesis, Porto Alegre: Pontifícia Universidade Católica do Rio Grande do Sul.

Instituto Brasileiro de Geografia e Estatística (2010). Censo 2010. http://www.censo2010.ibge.gov.br/

Katz, S., Ford, A. B., Moskowitz, R. W., Jackson, B. A., \& Jaffe, M. W. (1963). Studies of Illness in the Aged. The Index of ADL: A Standardized Measure of Biological and Psychosocial Function. The Journal of the American Medical Association, 185, 914-919. http://dx.doi.org/10.1001/jama.1963.03060120024016

Lawton, M. P., \& Brody, E. M. (1969). Assessment of Older People: Self-Maintaining and Instrumental Activities of Daily Living. Gerontologist, 9, 179-186. http://dx.doi.org/10.1093/geront/9.3_Part_1.179

Lebrão, M. L., \& Laurenti, R. (2005). Saúde, bem-estar e envelhecimento: O estudo SABE no Município de São Paulo. Revista Brasileira de Epidemiologia, 8, 127-141. http://dx.doi.org/10.1590/S1415-790X2005000200005

Lima, Â. M. M., Silva, H. S., \& Galhardoni, R. (2008). Envelhecimento bem-sucedido: Trajetórias de um constructo e novas fronteiras. Interface-Comunicação, Saúde, Educação, 12, 795-807. http://dx.doi.org/10.1590/S1414-32832008000400010

Lima-Costa, M. F., Firmo, J. O. A., \& Uchôa, E. (2004). A estrutura da auto-avaliação da saúde entre idosos: Projeto Bambuí. Revista de Saúde Pública, 38, 827-834. http://dx.doi.org/10.1590/S0034-89102004000600011

Lima-Costa, M. F., Peixoto, S. V., Matos, D. L., Firmo, J. O. A., \& Uchôa, E. (2007). A influência de respondente substituto na percepção de saúde de idosos: Um estudo baseado na Pesquisa Nacional por Amostra de Domicílios (1998, 2003) e na coorte de Bambuí, Minas Gerais, Brasil. Cadernos de Saúde Pública, 23, 1893-1902. http://dx.doi.org/10.1590/S0102-311X2007000800016

Maia, F. O. M., Duarte, Y. A. O., Lebrão, M. L., \& Santos, J. L. F. (2006). Fatores de risco para mortalidade em idosos. Revista de Saúde Pública, 40, 1049-1056. http://dx.doi.org/10.1590/S0034-89102006005000009

Marcellini, F., Leonardi, F., Marcucci, A., \& Freddi, A. (2002). Health Perception of Elderly People: The Results of a Longitudinal Study. Archives of Gerontology and Geriatrics, 35, 181-189. http://dx.doi.org/10.1016/S0167-4943(02)00131-0

Mendes da Costa, E., Godin, I., Pepersack, T., Coppieters, Y., \& Levêque, A. (2013). Analysis of Factors Influencing Self- 
Rated Health among Older Persons: Synthesis of the Biomedical Literature. Gériatrie et Psychologie Neuropsychiatriedu Vieillissement, 11, 339-350.

Nunes, A. P. N., Barreto, S. M., \& Gonçalves, L. G. (2012). Relações sociais e autopercepção da saúde: Projeto envelhecimento e saúde. Revista Brasileira de Epidemiologia, 15, 415-428. http://dx.doi.org/10.1590/S1415-790X2012000200019

Oliveira, D. C., Neri, A. L., \& D’Elboux, M. J. (2013). Variáveis relacionadas à expectativa de suporte para o cuidado de idosos residentes na comunidade. Revista Latino-Americana de Enfermagem, 21, 742-749. http://dx.doi.org/10.1590/S0104-11692013000300013

Pagotto, V., Bachion, M. M., \& Silveira, E. A. (2013). Autoavaliação da saúde por idosos brasileiros: Revisão sistemática da literatura. Revista Panamericana de Salud Pública, 33, 302-310. http://dx.doi.org/10.1590/S1020-49892013000400010

Pagotto, V., Nakatani, A. Y. K., \& Silveira, E. A. (2011). Fatores associados à autoavaliação de saúde ruim em idosos usuários do Sistema Único de Saúde. Cadernos de Saúde Pública, 27, 1593-1602. http://dx.doi.org/10.1590/S0102-311X2011000800014

Parahyba, M. I., Veras, R., \& Melzer, D. (2005). Incapacidade Funcional Entre as Mulheres Idosas No Brasil. Revista de Saúde Pública, 39, 383-391. http://dx.doi.org/10.1590/S0034-89102005000300008

Paskulin, L. M. G., \& Vianna, L. A. C. (2007). Perfil sociodemográfico e condições de saúde auto-referidas de idosos de Porto Alegre. Revista de Saúde Pública, 41, 759-768. http://dx.doi.org/10.1590/S0034-89102007000500010

Rosa, T. E. C., Benício, M. H. A., Latorre, M. R. D. O., \& Ramos, L. R. (2003). Fatores determinantes da capacidade funcional entre idosos. Revista de Saúde Pública, 37, 40-48. http://dx.doi.org/10.1590/S0034-89102003000100008

Santos, R. L., \& Virtuoso Júnior, J. S. (2008). Confiabilidade da versão brasileira da escala de atividades instrumentais da vida diária. Revista Brasileira em Promoção da Saúde, 21, 290-296. http://dx.doi.org/10.5020/18061230.2008.p290

Silva, T. R., \& Menezes, P. R. (2007). Autopercepção de saúde: Um estudo com idosos de baixa renda de São Paulo. Revista de Medicina, 86, 28-38. http://dx.doi.org/10.11606/issn.1679-9836.v86i1p28-38

Singh-Manoux, A., Gueguen, A., Martikainen, P., Ferrie, J., Marmot, M., \& Shipley, M. (2007). Self-Rated Health and Mortality: Short- and Long-Term Associations in the Whitehall II Study. Psychosomatic Medicine, 69, 138-143. http://dx.doi.org/10.1097/PSY.0b013e318030483a

Södergren, M., McNaughton, S. A., Salmon, J., Ball, K., \& Crawford, D. A. (2012). Associations between Fruit and Vegetable Intake, Leisure-Time Physical Activity, Sitting Time and Self-Rated Health among Older Adults: Cross-Sectional Data from the WELL Study. BMC Public Health, 12, 551. http://dx.doi.org/10.1186/1471-2458-12-551

Sun, W., Watanabe, M., Tanimoto, Y., Shibutani, T., Kono, R., Saito, M., Usuda, K., \& Kono, K. (2007). Factors Associated with Good Self-Rated Health of Non-Disabled Elderly Living Alone in Japan: A Cross-Sectional Study. BMC Public Health, 7, 297. http://dx.doi.org/10.1186/1471-2458-7-297

Theme-Filha, M. M., Szwarcwald, C. L., \& Souza Junior, P. R. B. (2008). Medidas de morbidade referida e inter-relações com dimensões de saúde. Revista de Saúde Pública, 42, 73-81. http://dx.doi.org/10.1590/S0034-89102008000100010

Torija, J. R. U., Mayor, J. M. F., Salazar, M. P. G., Buisán, L. T., \& Fernández, R. M. T. (2007). Síntomasdepresivos em personas mayores: Prevalencia y factoresasociados. Gaceta Sanitaria, 21, 37-42. http://dx.doi.org/10.1157/13099119

Wang, J. J., Smith, W., Cumming, R. G., \& Mitchell, P. (2006). Variables Determining Perceived Global Health Ranks: Findings from a Population-Based Study. Annals Academy of Medicine Singapore, 35, 190-197.

Yao, L., \& Robert, S. A. (2008). The Contributions of Race, Individual Socioeconomic Status, and Neighborhood Socioeconomic Context on the Self-Rated Health Trajectories and Mortality of Older Adults. Research on Aging, 30, $251-273$. http://dx.doi.org/10.1177/0164027507311155

Yesavage, J. A., Brink, T. L., Rose, T. L., Lum, O., Huang, V., Adey, M., \& Leirer, V. O. (1983). Development and Validation of a Geriatric Depression Screening Scale: A Preliminary Report. Journal of Psychiatric Research, 17, 37-49. http://dx.doi.org/10.1016/0022-3956(82)90033-4 